\title{
Role of kisspeptin and RFRP on the circadian control of female reproduction
}

Matthew BEYMER, Jo HENNINGSEN, Thibault BAHOUGNE* and Valérie SIMONNEAUX

Institut des Neurosciences Cellulaires et Intégratives (CNRS UPR 3212), 5 rue Blaise Pascal, 67084

Strasbourg, France

* Service d'Endocrinologie et Diabète, Hôpital Civil, Hôpitaux Universitaires de Strasbourg, Strasbourg, France

Corresponding author: V. Simonneaux, simonneaux@inci-cnrs.unistra.fr, tel: 33 (3) 88456671

\begin{abstract}
In female mammals, reproduction shows ovarian and daily rhythms ensuring that the timing of the greatest fertility coincides with maximal activity and arousal. The ovarian cycles, which lasts from a few days to a few weeks, depends on the rhythm in follicle maturation and ovarian hormone production, whereas the daily cycle depends on a network of circadian clocks of which the main one is located in the suprachiasmatic nuclei (SCN). In the last ten years, major progress has been made in the understanding of the neuronal mechanisms governing mammalian reproduction with the finding that two hypothalamic Arg-Phe-amide peptides, kisspeptin and RFRP, regulate GnRH neurons. In this review we discuss the pivotal role of Kp and RFRP neurons at the interface between the SCN clock signal and the GnRH neurons to time the gonadotropin-induced ovulation. We also report recent findings indicating that these neurons may be part of the multi-oscillatory circadian system that times female fertility. Finally, we will discuss recent investigations indicating a role, and putative therapeutic use, of these neuropeptides in human reproduction.
\end{abstract}




\section{Introduction}

Timing of reproduction in mammals has to be tightly correlated to both body fitness and optimal environmental cues in order to insure offspring survival. Thus, most species display a marked seasonal rhythm in reproduction with birth occurring in spring and early summer when food supply and temperature are most favorable. Additionally, females display cycles of ovarian activity lasting 45 days in rodents and about 28 days in women. Ovarian activity is mainly regulated by the hypothalamic GnRH control of the pituitary follicle stimulating (FSH) and luteinizing (LH) hormones. Briefly, during the first part of the ovarian cycle FSH production promotes follicular growth leading to a progressive increase of the sex steroid hormone, estradiol (E2). The high circulating level of E2 exerts a positive feedback in the central nervous system leading to a marked and transient secretion of LH which triggers ovulation of mature follicles. This preovulatory LH surge is strictly gated at the beginning of the active period, ensuring that ovulation occurs during optimal arousal and locomotoractivity. From the seminal pharmacology study of Everett and Sawyer (1950)[1] who reported that injection of barbiturate within a $2 \mathrm{~h}$-period of time, delayed preovulatory LH surge by $24 \mathrm{~h}$, to more recent genetic studies reporting that clock gene deletion in mice strongly impairs estrous cyclicity [2], it is now well established that a proper female reproduction requires a functional circadian system.

\section{Circadian clock and outputs to the reproductive network}

Most biological functions display daily rhythms governed by a network of endogenous circadian clocks synchronized with each other as well as with the $24 \mathrm{~h}$ cycle of environmental cues, principally the recurrent light/dark cycle. Proper female reproduction depends on a synchronized circadian system to reliably time the preovulatory LH surge at the onset of daily activity (early night in nocturnal species like mice and rats, and early day in diurnal species like humans). The mechanisms by which biological functions are synchronized to the light/dark signals involve the master biological clock located in the hypothalamic suprachiasmatic nuclei $(\mathrm{SCN})$ and the retino-hypothalamic tract which forwards the non visual light to the SCN. 
The demonstration that a biological clock is located in the basal hypothalamus came from experiments reporting that SCN lesions in rodents abolished circadian rhythms in locomotor activity, which were restored after exogenous SCN implants [3,4]. Each neuron of the SCN displays a circadian activity driven by a complex molecular system composed of transcription-translation loops cycling with a period of about one day (circa 'around'- dies 'day'). This molecular clockwork includes the CLOCK/BMAL1 dimer, which binds to a specific E-box (CACGTG) to promote the transcription of other clock genes Per1, Per2, Cry1 and Cry2, whose proteins in turn form dimers, which repress their own transcription by competing with the CLOCK/BMAL1 binding [5]. This main regulatory loop is modulated by secondary activatory or inhibitory components, such as REV-ERBa and RORb, and by kinases, which alter clock protein activity. The SCN circadian activity is primarily synchronized to a 24h-period by the daily light/dark signal via a non-visual pathway, mediated by the melanopsincontaining intrinsically photosensitive retinal ganglion cells, which project directly to the SCN [6]. Upon activation by light, these ganglion cell terminals release glutamate and pituitary activating cAMP peptide, which change the phase of the molecular clockwork thus leading to its synchronization to the $24 \mathrm{~h}$ light/dark cycle. Importantly, the CLOCK/BMAL1 dimer also regulates the daily expression of other genes such as arginine vasopressin (AVP), one of the most important outputs of the SCN clock [7].

Various experiments have demonstrated that proper female reproduction requires an intact circadian system. Thus, SCN lesions in female rats [8] or Clock or Bmal1 mutations in female mice [911] result in an impaired LH surge and abnormal estrous cyclicity. Furthermore, it is reported that women with single-nucleotide polymorphisms in ARNTL (Bmal1) have more miscarriages than those without [12]. It is now accepted that the gating of the preovulatory LH surge at a time closely preceding general activity onset is initiated by a SCN-derived stimulatory signal [13]. However, although this signal occurs every day, it is only effective at stimulating GnRH neurons to produce the LH surge when E2 secretion by mature ovarian follicles has reached a critical threshold, such as on the day of proestrus. The occurrence of this daily stimulatory SCN signal can be unmasked by 
implanting female rodents with capsules that result in proestrus-like concentrations of E2; in this case, an LH surge occurs every day $[13,14]$.

Neuroanatomical and physiological studies have pointed to two SCN neural outputs signaling daily information to the reproductive axis, AVP, in the dorsomedial part, and vasoactive intestinal peptide (VIP), in the ventrolateral part of the SCN. The content of VIP displays daily variation under light/dark conditions but not in constant darkness suggesting that VIP may transmit lighting information [15]. Of note, the daily rhythm in VIP mRNA displays sex-dependent variation in the rat $\mathrm{SCN}$, with a maximum reached during daytime in females and during nighttime in males [16]. AVP gene transcription in the SCN is directly controlled by the dimer CLOCK/BMAL1 [7], thus the SCN content of AVP and its release in the cerebrospinal fluid displays a daily rhythm which is maintained in constant darkness with a maximum reached at midday [16-20].

Early experiments have pointed to a critical role of AVP in the timing of the GnRH-induced LH surge. Central administration of AVP in SCN lesioned, ovarectomized and E2-treated rats was able to induce an LH surge whereas treatment with an AVP receptor, V1a, antagonist resulted in a reduction of the E2-induced LH surge [21,22]. Additionally, SCN originating, VIP fibers have been identified contacting GnRH neurons which express the VIP receptor $\left(\mathrm{VPAC}_{2}\right)$ [23-25]. Interestingly, VIP afferents on GnRH neurons are sexually dimorphic, with female rats exhibiting higher VIPergic innervation than males [26]. In line with these neuroanatomical observations, pharmacological studies support the involvement of VIP in the control of preovulatory LH surge, in that blocking $\mathrm{VPAC}_{2}$ attenuates $\mathrm{GnRH}$ neuronal cell firing during the afternoon surge in female mice [27] and central administration of VIP antiserum reduces the LH surge in female rats [28].

Altogether, these studies indicate that the $\mathrm{SCN}$ clock uses two neuropeptidergic pathways to signal time of the day to the reproductive system, an activatory AVPergic pathway and a VIPergic pathway modulating GnRH neuronal activity. 


\section{Kisspeptin in the daily control of reproduction in female}

\subsection{KISSPEPTIN (KP) NeUROANATOMY AND RELEVANCE IN REPROdUCtION}

The KiSS1 gene was first identified in 1996 in Hershey, PA and was named after the famous chocolate 'Kisses' produced in the town [29]. KiSS1 encodes a precursor 145 amino acid peptide, which is cleaved to a 54 amino acid protein named kisspeptin (Kp)-54. Kp-54 can be further cleaved to amino acids: Kp-14, -13 , and -10 sharing the same C-terminal decapeptide sequence [30]. In 2001, Kp was identified as a ligand for the orphan G-protein coupled receptor 54 (GPR54 in mammalian species/KISS1R for human, Kiss1r for non human), which was first described in the rat brain and subsequently in human (also known as AXOR12 and hOT7T175) [30-32]. In 2003, two independent studies reported that humans with deficiency or mutations in the GPR54 gene caused complete disruption of the reproductive axis leading to infertility $[33,34]$ which suggests that both $\mathrm{Kp}$ and its cognate receptor, GPR54, are essential for normal reproductive function.

There are two main hypothalamic Kp populations which have been described in the rodent brain: one in the anteroventral periventricular (AVPV) nucleus of the preoptic area (POA) and a second in the arcuate (ARC) nuclei of the mediobasal hypothalamus (MBH) [35-37]. The AVPV Kp neurons seem to be involved in the $E_{2}$-induced LH surge which occurs during the proestrus stage of the estrous cycle [37-39]. On the other hand, the ARC Kp population is believed to regulate the constant tonic/pulsatile secretion of $\mathrm{LH}$, which is important for proper ovarian maintenance including fostering growth and maturation of developing follicles [40]. The ARC Kp population co-expresses two other peptides, neurokinin B and dynorphin, which has earned this population the name KNDy neurons [41].

\subsection{MODES AND SITES OF ACTION}

The two populations of Kp neurons project to multiple overlapping regions in the rodent brain. Both AVPV and ARC Kp neurons project to the organum vasculosum of lamina terminalis (OVLT), AVPV, median preoptic nucleus, preoptic periventricular nucleus, medial preoptic nucleus, and medial and 
lateral regions of the septum [42-44]. Furthermore, ARC Kp fibers have been found in the supraoptic nucleus, bed nuclei of stria terminalis, anterior and lateral hypothalamic areas (LHA and AHA), paraventricular nucleus, SCN, posterior hypothalamic area, dorsomedial hypothalamic nucleus (DMH), internal zone of the median eminence as well as throughout the ARC itself $[42,44-46]$. AVPV Kp fibers make contact with a majority of $\mathrm{GnRH}$ cell bodies and proximal dendrons. Although ARC Kp fibers can be found in many regions containing GnRH neurons there is no direct evidence that ARC Kp make contact with GnRH cell bodies [42,44-46], however they have been found to make contact with GnRH dendrons passing through the ARC as well as coming in close proximity to GnRH terminals in the median eminence [44,47].

Many studies have now established that $\mathrm{Kp}$ acts directly on the activity of GnRH cells to evoke changes in gonadotropin secretion. Kp administration on acute brain slices is able to evoke a long lasting excitation of GnRH neurons [48]. Furthermore this study also demonstrated that E2 is able to potentiate this $\mathrm{Kp}$-induced excitation [48]. Interestingly, in vivo administration of $\mathrm{Kp}$, both central and peripheral, are able to evoke an increase in LH secretion. Intracerebroventricular (icv) injection of Kp in female mice significantly increased LH levels and this effect was blocked by pre-treatment with acyline, a GnRH antagonist, suggesting that the actions of Kp occur through GnRH $[49,50]$. Likewise, peripheral injection of Kp, either intravenously or intraperitoneally, was also able to elicit increased secretion of LH to similar levels seen through central administration [50].

Kp binds the G-protein coupled receptor Kiss1R [30], which has been found to be consistently expressed in several regions throughout the brain of several species including the medial and lateral septum, medial and rostral preoptic area, as well as in the ARC [51-53]. Approximately $90 \%$ of GnRH neurons have been found to co-express Kiss1R and this co-expression is similar between males and females [52,53]. 
There is a marked sex difference in the rostral population (AVPV) of Kp neurons in several species studied to date, with females having significantly more neurons than males [42]. This difference arises early during development since females treated with testosterone or estrogen, during a critical window in the neonatal period, have male-like Kp-immunoreactivity(ir) and KiSS1 gene expression in the AVPV $[54,55]$. Furthermore this difference could be the basis for the ability of females to elicit the LH surge, as these females with a 'masculinized' AVPV Kp population are unable to produce an LH-surge even when primed with E2 [56]. Several studies ranging on multiple species suggest that there is also a sex difference in ARC population of Kp neurons in that females have a higher expression than males [42,54,57-59].

There also appear to be sex differences in the electrical activity of Kp neurons in both the AVPV and ARC as well. In the ARC of male mice about $90 \%$ of Kp neurons showed spontaneous electrical activity where as only about half of Kp neurons in diestrus females were spontaneously active, which increased significantly to almost $70 \%$ in proestrus females [60]. In addition the mean firing rate in the ARC Kp cells of males was significantly higher than in females [60].

\subsection{KP IN THE DAILY CONTROL OF FEMALE REPRODUCTION}

To ensure reproductive success it is essential that the LH-surge, which induces ovulation, is properly timed. The AVPV Kp population is responsible for initiating the surge since more than $60 \%$ of there neurons are activated in the afternoon of proestrus as compared to only $5 \%$ activation of ARC Kp neurons at a similar time point [38]. Moreover, continuous infusion of anti-Kp into the POA of female rats is able to block the E2-induced LH-surge on the afternoon of proestrus [61]. Kp neurons in the AVPV show a significant daily variation in expression at both the mRNA and protein level, which appears to occur around the time of the LH surge during proestrus $[62,63]$. Accordingly, there is an increase of Kiss1 expression in the AVPV of E2-treated OVX female mice around the time of the LHsurge [62]. Robertson et al. also showed that Kp neurons in the AVPV exhibit more neuronal activity during the timing of the LH surge [62]. Furthermore, OVX female mice not treated with E2 do not 
show any of these circadian variations during proestrus [62]. Another recent study using intact mice corroborated the increase in Kiss1 mRNA around the time of the LH surge [63]. Interestingly, this study also demonstrated that there was a transient but significant decrease in Kp-ir in the AVPV 2 hours before the LH surge, which did not occur during diestrus [63]. Altogether these data strongly support that there is a tightly regulated variation in Kp neuronal activity, which depends on the presence of high levels of circulating E2 since these variations are abolished in either OVX or diestrus animals.

Electrophysiological studies have demonstrated that Kp neurons in the AVPV also exhibit changes in firing patterns and firing rates throughout the estrous cycle. In diestrus, AVPV Kp neurons exhibit primarily irregular firing patterns, which switch to a predominantly tonic firing pattern during proestrus [64]. The mean firing rate of AVPV Kp neurons is also elevated during proestrus as compared to estrus [64]. Interestingly, in this study they also tested the ability of AVP and VIP to alter the firing rate or pattern of AVPV Kp neurons; however neither peptide elicited a response [64]. Furthermore, there was no effect on rate or pattern of neuronal activity after application of an AVP receptor antagonist [64]. Another recent study using transgenic Kiss-GFP mice reported that the mean firing rate of AVPV Kp neurons was not significantly increased during the initiation of the surge but that there was a decrease in firing rate after the surge, coinciding with the beginning of the dark period and locomotor activity [60]. Furthermore, as compared to ARC Kp neurons, AVPV Kp neurons were constantly active and even showed up to $40 \%$ burst firing during proestrus [60].

Neuroanatomical studies now indicate that SCN-generated AVP fibers signal the time of day to GnRH neurons indirectly via Kp neurons in the AVPV. A number of AVP-containing axons of SCN origin make appositions to AVPV Kp neurons which express V1a receptors $[65,66]$. Importantly, these neurons also express a high number of estrogen receptor a (ERa) [36] indicating that AVPV Kp neurons integrate both daily and E2 signals to gate the timing of the LH surge. Actually, E2 treatment significantly increases the number of AVP terminal appositions on individual Kp neurons [65] and 
furthermore, recent studies have reported that AVP activation of Kp neurons, both in vivo in female Syrian hamsters [66] and in vitro in Kp-GFP neurons [67], requires high levels of E2.

Furthermore, it seems that AVPV Kp neurons respond to AVP regardless of the time of day; however only AVP administration during a narrow time window is able to elicit the $\mathrm{LH}[66,68]$. These findings indicate that the stimulatory effect of AVP on Kp neurons does not depend on the time of day, suggesting that the daytime gating of the LH surge does not rely on AVP input to Kp neurons but rather downstream at the Kp input/ GnRH neuron interaction [66].

A recent study from our group provided evidence for the presence of an E2 sensitive circadian clock in Kp neurons of the AVPV (Kiss-Clock). These neurons display a daily rhythm in the clock protein PER1 which was significantly phase delayed as compared to the PER1 rhythm in the SCN [63]. Interestingly the phase delay was shorter in the AVPV of female mice in proestrus than in diestrus (4.3 hours delay vs. 8 hours delayed), and moreover, the period of this Kiss-Clock was lengthened by approximately 1 hour after treatment with E2. This E2-induced lengthening could correspond to the slightly longer period seen during proestrus as compared to diestrus [63]. The exact role of this KissClock in the control of proper reproductive timing is still unknown but it is highly likely that this is another important factor in coordinating all the converging upstream signals in order to appropriately time the initiation of the LH surge.

Given the above data it is tempting to hypothesize that the daily signal from AVPergic inputs from the $\mathrm{SCN}$ onto $\mathrm{Kp}$ are part of the key mechanism for timing the $\mathrm{LH}$ surge. Most likely there is a complex gating caused by threshold levels of E2 which are typically only present during proestrus as demonstrated by the studies mentioned earlier in this section. From these data it is evident that $\mathrm{Kp}$ is one of the key factors relaying the environmental cues of the time of day to the reproductive axis.

\section{RFRP in the daily control of female reproduction}

\subsection{RFAMIDE-RELATED PEPTIDE (RFRP) NEUROANATOMY AND RELEVANCE IN REPRODUCTION}


RF (Arg-Phe) amide-related peptides (RFRPs) were first discovered in birds and mammals in 2000 $[69,70]$. In birds, the peptide was shown to inhibit gonadotropin secretion from cultured quail pituitaries and therefore named gonadotropin-inhibitory hormone $(\mathrm{GnIH})$ [69]. The mammalian gene, named RFamide-related peptide (Rfrp), encodes RFRP-1, -2 and -3 peptides, of which RFRP-1 and RFRP-3 are functional peptides [70-72].

RFRP-3 and GnIH have been shown to inhibit GnRH neuron activity and gonadotropin release in several species [69,73-78]. In line with these first observations, GPR147 deficient mice (cognate receptor for RFRP peptides), exhibit increased gonadotropin levels, dependent on the developmental stage, and slightly increased litter sizes as compared to wild type mice [79]. In contrast to this, we have recently shown that central administration of RFRP-3 stimulates gonadotropin secreation in male Syrian hamsters [80] with a similar stimulatory effect of RFRP-3 being reported in male Siberian hamsters as well [81]. Altogether these studies indicate that the effect of the peptide is speciesdependent. Strikingly, while RFRP-3 activates the reproductive axis in male Syrian hamsters [80], the avian GnIH inhibits LH secretion in OVX females [77], further implying that there are sex-differences in the effects of the peptides.

\subsection{MODES AND SITES OF ACTION}

RFRP neurons project to multiple regions of the rodent brain, including the preoptic area, in and around the OVLT, AVPV/medial preoptic nucleus (MPN), the anterior part of the SCN, PVN, anterior hypothalamus, VMH and ARC as well as in the bed nucleus of the stria terminalis (BNST), habenular nuclei $(\mathrm{Hb})$, and paraventricular nucleus of the thalamus $[77,81,82]$. RFRP fiber terminals make apparent contact to $20-40 \%$ of GnRH somas in rodents and sheep $[77,81,83,84]$, and in female mice, around $20 \%$ of AVPV Kp neurons and $35 \%$ of ARC Kp neurons receive RFRP-fiber contacts [83,85], strongly implying that RFRP acts at several and central sites to regulate reproductive activity. Indeed, several studies report that RFRP neurons directly modulate the activity of a subpopulation of GnRH cells $[73,77,80,81,83,86]$. In mice, application of RFRP-3 to brain slices inhibits the firing rate of $41 \%$ 
GnRH neurons, while stimulating the firing rate of $12 \%$ of the GnRH neurons [75], the remainder being unaffected. Furthermore, in male Syrian hamsters, central administration of RFRP-3 induces cFos expression in $20-30 \%$ of GnRH neurons [80].

RFRP peptides bind preferentially to the G-protein coupled receptor, GPR147 (also known as NPFF1R). GPR147 has been found to couple to both stimulatory and inhibitory G protein subunits in vitro [87-89], however, the exact signaling events occurring downstream of GPR147 in its natural cellular environment remains to be established. GPR147-encoding mRNA is widely distributed in the brain, and is particularly strongly expressed in hypothalamic regions (OVLT, AVPV/MPN, SCN, PVN, $\mathrm{AH}, \mathrm{VMH}$ and $\mathrm{ARC}$ ) and outside (posterior part of the BNST, $\mathrm{Hb}$, and the pyramidal cell layer of the hippocampus) $[82,90,91]$. Interestingly, GPR147 has been shown to be expressed in $15-33 \%$ of mice GnRH neurons and a subpopulation of Kp neurons in the AVPV (5-16\%) and the ARC (25\%) $[83,85,86]$, further supporting that RFRP peptides acts directly on central neuroendocrine regulators of reproduction to exerts its effects.

\subsection{SEX DIFFERENCES IN THE RFRP SYSTEM}

As mentioned in 4.1, avian GnIH inhibits LH release in OVX female Syrian hamsters [77], which is in contrast to the stimulatory effect observed in male Syrian hamsters [80]. It is worth mentioning that GnIH contains an -LPLRFa motif similar to that of the mammalian RFRP-1 rather than RFRP-3, but we have recently found that acute injections of Syrian hamster RFRP-3, in brains of intact female Syrian hamsters, inhibits LH release similarly to the observed effect of GnlH (Henningsen et al., unpublished). To further explore the basis for such sex-difference in the effects of RFRP, we have recently examined the RFRP system in a comparative study between female and male Syrian hamsters [82]. Here, we revealed that there are sex-differences in the expression of RFRP and its receptor, GPR147 (NPFF1), in that the number and intensity of RFRP positive labeled neurons, as well as levels of GPR147 mRNA expression are higher in females than in males. Moreover, the number of RFRP-ir fibers projecting specifically to the AVPV is increased in sexually inactive female Syrian 
hamsters as compared to sexually active female Syrian hamsters, indicating that there might be an increased release of RFRP peptide in this region during sexual quiescence [82], which fits well with the reported inhibitory effect of the peptide in the female. A similar sex-difference in RFRP expression has been reported in the rat, where RFRP-1 expression is found to be higher in females as compared to males [92]. Altogether these findings point towards a particular importance of the RFRP system in regulating female reproductive activity.

\subsection{RFRP IN THE DAILY CONTROL OF FEMALE REPRODUCTION}

It has recently been suggested that RFRP neurons are regulated by an SCN-generated circadian output to modulate the timing and generation of the LH surge. Indeed, Gibson et al., (2008) have shown that RFRP-ir cell numbers as well as their activation, by means of c-Fos positive labeled neurons, are decreased at the time of the $\mathrm{LH}$-surge on the day of proestrus as compared to other time points on the day of proestrus and on the day of diestrus [93]. Similarly, in rats, the activation of RFRP neurons is specifically decreased on the day of proestrus [92] and in ewes, RFRP expression is reduced during the pre-ovulatory period [94]. Moreover, chronic icv infusion of RFRP-3 in OVX rats inhibits the activity of GnRH neurons and AVPV neurons during an E2- and progesterone-induced LHsurge in OVX rats [73]. Altogether, these findings point towards a specific daily rhythm in RFRP expression and release in females, which serves to down-regulate RFRP activity at the time of the LHsurge, which might be necessary for proper generation and/or timing of the LH-surge.

Using an anterograde tracing approach in the female Syrian hamster, Gibson et al., (2008) show that fibers originating from the $\mathrm{SCN}$ project to the $\mathrm{DMH}$ where they form close appositions to RFRP neurons. By maintaining animals in conditions of constant light, they demonstrate that hamsters experiencing splitting in their behavior and thereby anti-phase oscillation between the right and left SCN, which leads to two daily LH-surges along with an opposite asymmetrical activation of GnRH and RFRP neurons. These findings further suggest that the SCN suppresses RFRP activity while simultaneously stimulating GnRH activity associated with the LH-surge [93]. More recent data from 
the same group reveals that SCN-derived VIP neuronal projections form close appositions to RFRP neurons in female Syrian hamsters and that central administration of VIP significantly suppresses RFRP cellular activity, but only when injected in the afternoon of proestrus and not in the morning [95]. Therefore, it seems likely that an SCN-derived VIP-ergic signal is responsible for decreasing RFRP activity in the late afternoon of proestrus thereby allowing a full activation of the LH-surge. No colocalization was however observed between RFRP cells and the VIP receptor and therefore suggests that VIP regulation of RFRP neurons is indirect [95]. Interestingly, this study also demonstrated that RFRP cells express PER1 with a diurnal variation having a peak co-expression at ZT12 [95] which could indicate that RFRP neurons have the ability to keep circadian time in some manner, similar to what we have recently demonstrated in Kp neurons [63].

To date, the effects of RFRP peptide administration on the female reproductive axis, have primarily been investigated in OVX animals, in order to bypass any potential influence of circulating sex steroids $[73,74,77,78,94,96]$. Despite some contradictions, RFRP seems to have a predominantly inhibiting effect on reproductive activity in females. In OVX rats $[73,78,96]$ and Syrian hamsters [77], central administration of RFRP-3 or GnIH, respectively, inhibits artificially elevated plasma LH levels. In OVX ewes, iv administration of ovine RFRP-3 peptide (also referred to as GnIH3) inhibits (pulsatile) LH release $[74,94]$ indicating that RFRP peptides furthermore have a hypophysiotropic effect in ovine species, similarly to what is observed in avian species. It should be stressed however, that the reported inhibitory effect of RFRP-3 in ewes, have been compromised by other findings [97,98], of which one recent extensive study finds no variation in LH plasma concentrations in neither ovariectomized nor intact ewes injected either intracerebroventricular (icv) or iv with RFRP-3 [98].

\section{E2 feedback on Kp and RFRP neurons}

\section{1 IMPORTANCE OF E2 IN THE REPRODUCTIVE AXIS}

Over several decades, sex steroid hormones, especially E2, have been established as crucial signals for the proper development and functioning of the reproductive axis. One key feature of action is the 
ability of sex steroids to feedback to the brain in order to control output from the hypothalamus and pituitary. It would be tempting to hypothesize that this feedback occurs directly at the level of GnRH neurons; however this seems to not be the case, since GnRH neurons only express estrogen receptor beta $(E R \beta)$ but not $E R a$, which is the isoform implicated in the majority of the hormones feedback properties in the brain (Radovick et al. 2012). However, neuronal populations acting upstream of GnRH, specifically Kp and RFRP neurons, express ERa and show significant regulation of gene expression and neuronal activity by E2.

\subsection{KP AND E2 FEEDBACK}

Many studies have investigated the effects and mechanisms of sex steroid action on Kp neurons in the brain. Both populations of Kp neurons have been shown to express both ERa and ER $\beta$ in all mammalian species studied to date. Smith et al. (2005) showed that Kiss1 gene expression is significantly regulated by the presence or absence of sex steroid hormones. In female mice, ovariectomy (OVX) significantly decreases Kiss1 expression in the AVPV, while E2 restores Kiss1 expression to intact levels [36]. E2 regulates ARC Kiss1 expression in an opposite fashion with OVX increasing Kiss1 expression and E2-replacement decreasing expression back to intact levels [36]. These findings suggest that the AVPV Kp population is the site of E2 positive feedback and that the Kp population in the ARC nucleus is the primary site of negative feedback. Subsequently, this has evolved to our current understanding that the ARC population controls tonic release of $\mathrm{GnRH}$ and $\mathrm{LH}$, while the AVPV is the site that is involved in the E2-induced preovulatory surge of GnRH and LH.

Using Kp-specific ERa KO (KERKO) mice, Mayer and colleagues show that ERa in Kiss1-expressing neurons is necessary for the proper timing of pubertal onset as well as norm ovarian cyclicity further demonstrating the importance of E2 regulation of Kp cells. In these female KERKO mice Kiss1 expression in the AVPV is completely absent but seems to be relatively unaltered in the ARC $[99,100]$. Moreover, E2 treatment in OVX KERKO females is unable to suppress Kiss1 expression in the ARC and only minimally increased Kiss1 expression in the AVPV [100]. In conclusion, it is clear that E2 is very 
important for the proper development of Kp cells and for the ability of these cells to relay the levels of sex steroids to the GnRH neurons. Lastly, E2 is also required for the properly timed activation of AVPV Kp neurons during proestrus by the daily AVP signal from the SCN.

\subsection{RFRP AND E2 FEEDBACK}

The regulation of RFRP neurons by sex steroids, such as E2, has been widely studied, but there still remain some inconsistencies in the reported findings. Indeed, a portion of RFRP neurons has been shown to co-express ERa in both female Syrian hamsters and rats, indicating a direct effect of E2 on RFRP neurons [77,86,101]. In female Syrian hamsters, E2 has been shown to induce c-Fos expression in RFRP neurons [77], and similarly stimulates Rfrp expression in female rats [102]. Based on these findings it is possible that the sex-differences observed in rats and Syrian hamsters, with higher RFRP expression in females than in males [82,92], is driven by an E2-induced stimulation of RFRP expression in females. Interestingly, Gibson et al., (2008) found that the daily changes in RFRP activation, observed on the day of proestrus, are affected by E2. Removal of E2 disrupts the increase in RFRP activity observed in the evening of proestrus, after the LH-surge [93]. Based on these findings, E2 might be important for up-regulating RFRP activity after the LH-surge has taken place. This hypothesis, however, raises questions in regards to how and why RFRP activity could be positively regulated by E2 since RFRP neuronal activity is suppressed at the time to the LH-surge [95] when E2 levels are known to be high.

In contrast to the above-mentioned study, E2 was shown to decrease Rfrp expression in mice [86,101], whereas in OVX rats, treatment with E2 or progesterone has no effect on Rfrp levels [103]. Altogether, these findings indicate that RFRP expression might be regulated by E2, but that there might be differences in how RFRP expression is regulated by sex steroids among species. Additional studies are required in order to clarify this matter and to determine whether E2 accounts for the sexdifferences in RFRP expression observed in rats and Syrian hamsters, as well as to investigate the role 
of E2 in regulating daily changes in RFRP activity related to the generation of the pre-ovulatory LHsurge.

\section{Clinical relevance}

Most studies aiming at understanding the reproductive role and mechanisms of Kp and RFRP are done in rodents. However, increasing studies report that these neuropeptides, particularly Kp, are involved in human reproduction.

\subsection{KP AND RFRP IN THE HUMAN BRAIN}

The human brain has no true anatomical equivalent to the AVPV in rodents, however Kp neurons are found in the rostral part of the human hypothalamus, more specifically, the rostral and ventral periventricular hypothalamic nucleus $(\mathrm{PeN})$, the anterior parvocellular and magnocellular subdivisions of the paraventricular nucleus (PVN). Furthermore, this preoptic area displays a sexual dimorphism similar to the AVPV of rodents, where more Kp neurons are observed in female individuals than males, reflecting a sex steroid up-regulation $[59,104]$. Kp neurons are also found in the caudal hypothalamic infundibular (arcuate) nucleus [105] (Taziaux et al., 2016) where they co-expresses neurokin B and dynorphin $[59,106]$. Furthermore, over the life time, Kp neurons of this infundibular nucleus seems to be downregulated by highest concentration of sex-steroid-hormone (Hrabovszky et al., 2011)(Taziaux et al., 2016). Moreover, in adult male-to-female transsexuals, a female-typical kisspeptin expression was observed without sex steroid hormone correlation, excluding a possible inducible brain sexual differentiation (Taziaux et al., 2016). Interestingly, inactivating mutations have been described in the genes encoding for NKB and its cognate receptor, NK3R, resulting in normosmic isolated hypogonadotropic hypogonadism (niHH) with low levels of $\mathrm{LH}$, normal or nearnormal levels of FSH, and absence of puberty $[107,108]$. 
Both rostral and infundibular hypothalamic Kp neuronal populations project to GnRH neurons $[59,106]$. The human KISS1R encoding gene (AXOR12) exhibits $81 \%$ homology to the rat GPR54 gene and is highly expressed in various brain regions including the hypothalamus, cerebellum, cerebral cortex, and brainstem, as well as in the pituitary and placenta [31].

In 2009, RFRP-1 and RFRP-3 were identified by mass spectrometry in the human hypothalamus [109]. Further neuroanatomical analyses revealed RFRP-ir cell bodies in the dorsomedial region of the hypothalamus with axonal projections to $\mathrm{GnRH}$ neurons in the preoptic area as well as to the median eminence [109]. In this same study, GPR147 was found to be expressed in the human hypothalamus and pituitary [109].

\subsection{KP AND RFRP IN THE REGULATION OF HUMAN REPRODUCTION}

Since the two pioneering studies of De Roux et al. and Seminara et al. in 2003, increasing evidence indicates that $\mathrm{Kp}$ plays a key role in maintaining reproductive function and fertility in humans. Humans with mutations in Kiss1 or KISS1R have niHH, resulting in low concentrations of circulating $\mathrm{LH}$ and FSH and failure to advance through pubertal [110-115]. In contrast, a young girl with an activating mutation in KISS1R displayed an early onset of puberty [116]. In human pathology, KISS1 or KISS1R mutations are responsible for approximately $2 \%$ of the cases of hypogonadotropic hypogonadism [115].

No mutations in Npvf, the gene encoding RFRP in humans, or its receptor, GPR147, have yet been described in humans, however polymorphisms of Npvf have been observed in niHH and idiopathic central precocious puberty. This seems to indicate RFRP might play a secondary, modulatory role in the regulation of pubertal development [117]. Alternatively RFRP-3 may play a local role at the level of the ovary since genes coding RFRP-3 and GPR147 are both expressed in human granulosa cells and RFRP-3 is able to reduce gonadotropin-stimulated cAMP accumulation and progesterone synthesis [118]. 
Changes in Kp or RFRP expression throughout life have not been studied in women, except around the menopause, however studies performed in female primates revealed that the expression of hypothalamic KiSS-1 and GPR54 increases at the time of pubertal resurgence in GnRH release [119]. In adult female primates, the number of Kp cells in the POA and caudal ARC, as well as RFRP cells in the $\mathrm{DMH}$ were higher in the late follicular phase, just before the $\mathrm{GnRH} / \mathrm{LH}$ surge, than in the luteal phase [120]. Interestingly, the number of KP and RFRP fibers opposing GnRH neurons did not changed across the menstrual cycle [120].

During pregnancy, circulating levels of $\mathrm{Kp}$ increase up to 7000-fold during the third trimester as a consequence of an increased $\mathrm{Kp}$ expression in the placental syncytiotrophoblasts, and returns to normal levels five days after bith [121]. Some data suggests that $\mathrm{Kp}$ is important for trophoblast invasion as well as angiogenesis [122] and may play a role in maintaining pregnancy. Indeed, early bleeding [123], recurrent spontaneous abortions [124], metabolic alteration such as diabetes and hypertension [125] or development of pre-eclampsia [126-128] can all result from a lowered level of $\mathrm{Kp}$ and KISS1R expression in the placenta and suggests that $\mathrm{Kp}$ injections to women during late pregnancy could be a viable treatment to prevent complications due to deficient levels of Kp. Furthermore, recent experimental data gives evidence for a role of KISS/KISS1R signaling in rodent embryo implantation [129].

Comparison of hypothalamic samples from pre- and post-menopausal women, shows that Kp neurons in the hypothalamic infundibular (arcuate) nucleus are larger and more numerous in postmenopausal women due to the lack of estrogen negative feedback [105]. Such over-expression of Kp in post-menopausal women has been proposed to be responsible for the associated hot flushes caused by a cutaneous vasodilatation [130].

\subsection{KP AS A NEW TREATMENT FOR FERTILITY}

Dysregulation of GnRH secretion may lead to hypogonadotropic hypogonadism, infertility and disordered pubertal development. Previous studies have demonstrated that GnRH pump therapy 
effectively treats patients with absent LH pulsatility associated with hypogonadotropic hypogonadism, by inducing pharmacological pulses of LH secretion [131] sufficient to trigger ovulation [132]. However, after continuous (non pulsatile) GnRH administration, the initial stimulation is replaced by an inhibition (tachyphylaxis) due to a combined down-regulation of GnRH receptors and of gonadotrope desensitization [133-135].

The potent $\mathrm{Kp}$ stimulation up-stream of the GnRH neurons has been proposed as safe pharmacological treatment for infertility with lower risk. Indeed, there a re an increasing number of studies reporting $\mathrm{Kp}$ administration to women using different isoforms (Kp-54 or Kp-10), methods of administration (intravenous -iv, subcutaneous -sc), and types of exposure (single bolus, repeated or continuous administration). In humans, Kp-54 is the most common circulating isoform and sc injected Kp-54 is not degraded to smaller Kp fragments [136]. Kp-10 has a 7-fold shorter half-life than Kp-54 $[137,138]$ and a peak of circulating Kp-54 is observed between 15 min [136] and $60 \mathrm{~min}$ [139] after sc injection in women. Studies report that both Kp-10 and Kp-54 are well tolerated, without menstrual cyclicity alteration in healthy young women [140]. Although animal studies suggest that Kp-10 may stimulate growth hormone, prolactin and thyroid-stimulating hormone, such effects have not been reported in healthy women after a short period of Kp-54 injections, however a more comprehensive is needed [141-147]. Importantly, no effects on blood pressure, pulse pressure, or heart rate have been observed after treatment with different doses of Kp [136].

In healthy young women, single sc or iv injection of Kp-10 during the ovulatory phase induces a large increase in LH secretion (390 \%) whereas injections during the early follicular or luteal phases have very limited effects on LH secretion $[138,148,149]$. However, a low dose of Kp-54, injected during the late follicular phase, potently stimulates LH secretion $[138,139]$. These data suggest that this phase-dependent difference in Kp efficiency might be due to differences in E2 levels through the cycle. Interestingly, at the end of the follicular phase, Kp-10 induces a quicker release of LH than $\mathrm{Kp}-54$, this is possibly due to $\mathrm{Kp}-10$ stimulating the release of $\mathrm{GnRH}$ from the nerve endings in the 
median eminence, whereas Kp-54 might act on GnRH neuronal cell bodies in order to stimulate de novo GnRH synthesis $[140,149]$. Notably, repeated injections of Kp induce tachyphylaxis. Thus, one week of twice daily injections of Kp-54 first reduced LH then FSH secretion in healthy women and women with hypothalamic amenorrhea, without altering GnRH-induced gonadotropin secretion $[140,150]$. This desensitization could be due to the liberation of a massive stock of GnRH after the first injection, requiring time for de novo GnRH synthesis. Indeed, decreasing the frequency of Kp-54 injections lessens this tachyphylaxis [150]. An alternative explanation might be that high doses of Kp bind to GPR147, the receptor for the inhibitory RFRP-3. Recently, Kp-54 has been shown to be an effective treatment to stimulate oocyte maturation in women who have high risk of developing ovarian hyperstimulation syndrome during in vitro fertilization procedures [151,152].

\section{Conclusion}

Although much is known about how the circadian and reproductive systems function individually we are only beginning to understand the mechanisms and significance of their interaction. It is clear however that these interactions occur at many levels simultaneously through connections particularly of the SCN output and reproductive nuclei in the brain (Fig. 1). Understanding the precise nature of the timing of physiological reproductive events could lead to advances in the efficiency and productivity of breeding livestock, as well as increased success rates in human infertility treatments such as in vitro fertilization. 


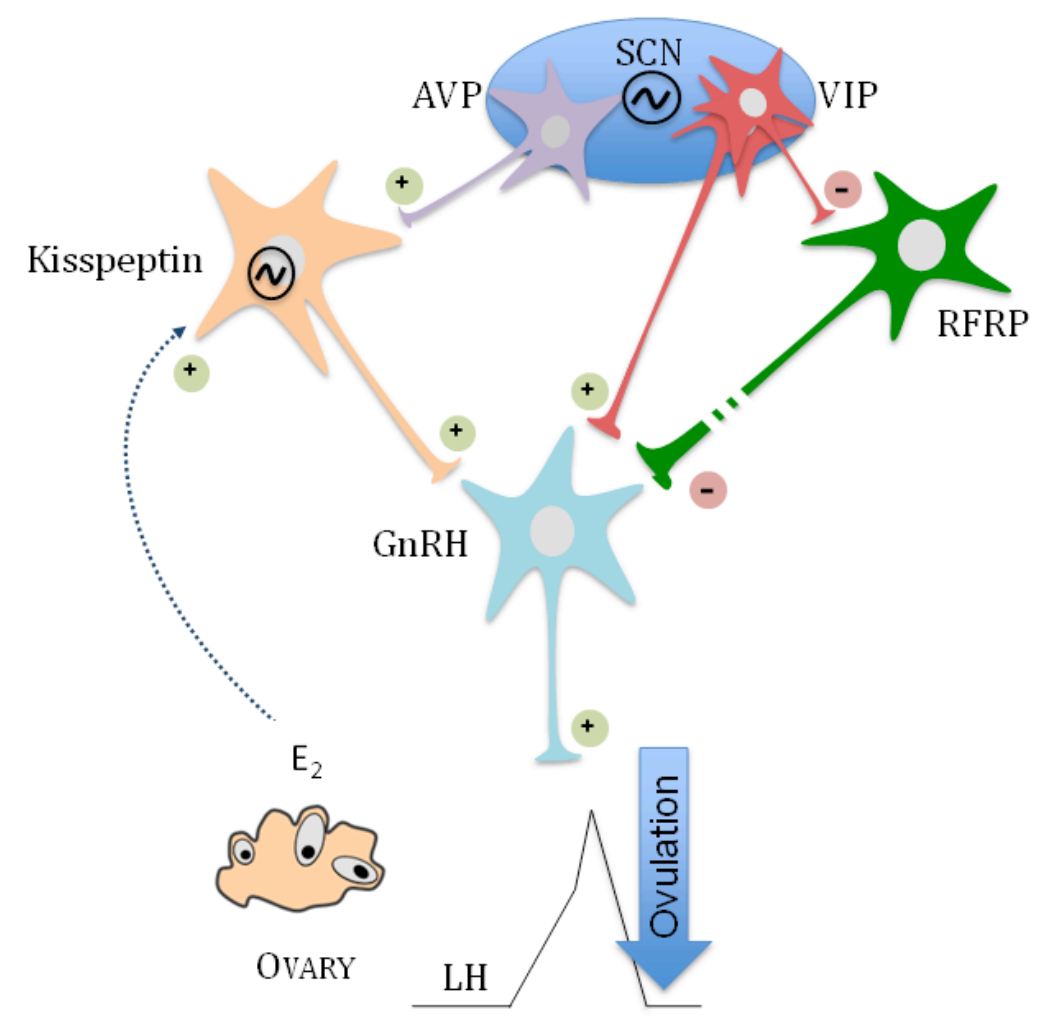

Figure legends.

Figure 1. Schematic representation of neuroendocrine pathways timing female reproduction. The master circadian clock, located in the suprachiasmatic nucleus (SCN), is synchronized to $24 \mathrm{~h}$ primarily by changes in the light/dark cycle. Two SCN-derived peptides forward the daily information to the reproductive axis. Arginine vasopressin (AVP) projects to and activates kisspeptin $(\mathrm{kp})$ neurons in the anteroventral periventricular nuclei (AVPV), leading to the activation of GnRH neurons. Vasoactive intestinal peptide (VIP) directly modulate and stimulate GnRH neuron activity, whereas RFRP neuron in the dorso/ventromedial hypothalamus (DMH) is indirectly inhibited in a rhythmic manner by VIP, possibly serving to lift a tonic inhibition from RFRP. The increased GnRH release activates the synthesis and release of the gonadotropins luteinizing hormone (LH), which in turn regulates follicle maturation, estradiol synthesis, and finally ovulation triggered by the LH surge.

\section{Funding}

This work was funded by the CNRS UPR 3212. 
[1] Everett, J.W. and Sawyer, C.H. (1950) A 24-hour periodicity in the "LH-release apparatus" of female rats, disclosed by barbiturate sedation. Endocrinology 47, 198-218.

[2] Miller, B.H. and Takahashi, J.S. (2013) Central circadian control of female reproductive function. Front Endocrinol (Lausanne) 4, 195.

[3] Lehman, M.N., Silver, R., Gladstone, W.R., Kahn, R.M., Gibson, M. and Bittman, E.L. (1987) Circadian rhythmicity restored by neural transplant. Immunocytochemical characterization of the graft and its integration with the host brain. J Neurosci 7, 1626-38.

[4] Ralph, M.R. and Lehman, M.N. (1991) Transplantation: a new tool in the analysis of the mammalian hypothalamic circadian pacemaker. Trends Neurosci 14, 362-6.

[5] Lowrey, P.L. and Takahashi, J.S. (2011) Genetics of circadian rhythms in Mammalian model organisms. Adv Genet 74, 175-230.

[6] Berson, D.M., Dunn, F.A. and Takao, M. (2002) Phototransduction by retinal ganglion cells that set the circadian clock. Science $295,1070-3$.

[7] Jin, X., Shearman, L.P., Weaver, D.R., Zylka, M.J., de Vries, G.J. and Reppert, S.M. (1999) A molecular mechanism regulating rhythmic output from the suprachiasmatic circadian clock. Cell 96, 57-68.

[8] Brown-Grant, K. and Raisman, G. (1977) Abnormalities in reproductive function associated with the destruction of the suprachiasmatic nuclei in female rats. Proc R Soc Lond B Biol Sci 198, 279-96.

[9] van der Horst, G.T., Muijtjens, M., Kobayashi, K., Takano, R., Kanno, S., Takao, M., de Wit, J., Verkerk, A., Eker, A.P., van Leenen, D., Buijs, R., Bootsma, D., Hoeijmakers, J.H. and Yasui, A. (1999) Mammalian Cry1 and Cry2 are essential for maintenance of circadian rhythms. Nature 398, 627-30.

[10] Miller, B.H., Olson, S.L., Turek, F.W., Levine, J.E., Horton, T.H. and Takahashi, J.S. (2004) Circadian clock mutation disrupts estrous cyclicity and maintenance of pregnancy. Curr Biol 14, 1367-73.

[11] Chu, A., Zhu, L., Blum, I.D., Mai, O., Leliavski, A., Fahrenkrug, J., Oster, H., Boehm, U. and Storch, K.F. (2013) Global but not gonadotrope-specific disruption of Bmal1 abolishes the luteinizing hormone surge without affecting ovulation. Endocrinology 154, 2924-35.

[12] Kovanen, L., Saarikoski, S.T., Aromaa, A., Lonnqvist, J. and Partonen, T. (2010) ARNTL (BMAL1) and NPAS2 gene variants contribute to fertility and seasonality. PLoS One 5, e10007.

[13] Christian, C.A., Mobley, J.L. and Moenter, S.M. (2005) Diurnal and estradiol-dependent changes in gonadotropin-releasing hormone neuron firing activity. Proc Natl Acad Sci U S A 102, $15682-7$.

[14] Legan, S.J. and Karsch, F.J. (1975) A daily signal for the LH surge in the rat. Endocrinology 96, 57-62.

[15] Shinohara, K., Tominaga, K., Isobe, Y. and Inouye, S.T. (1993) Photic regulation of peptides located in the ventrolateral subdivision of the suprachiasmatic nucleus of the rat: daily variations of vasoactive intestinal polypeptide, gastrin-releasing peptide, and neuropeptide $Y$. J Neurosci 13, 793-800.

[16] Krajnak, K., Kashon, M.L., Rosewell, K.L. and Wise, P.M. (1998) Sex differences in the daily rhythm of vasoactive intestinal polypeptide but not arginine vasopressin messenger ribonucleic acid in the suprachiasmatic nuclei. Endocrinology 139, 4189-96.

[17] Schwartz, W.J. and Reppert, S.M. (1985) Neural regulation of the circadian vasopressin rhythm in cerebrospinal fluid: a pre-eminent role for the suprachiasmatic nuclei. J Neurosci 5 , 2771-8. 
[18] Gillette, M.U. and Reppert, S.M. (1987) The hypothalamic suprachiasmatic nuclei: circadian patterns of vasopressin secretion and neuronal activity in vitro. Brain Res Bull 19, 135-9.

[19] Takahashi, Y., Okamura, H., Yanaihara, N., Hamada, S., Fujita, S. and Ibata, Y. (1989) Vasoactive intestinal peptide immunoreactive neurons in the rat suprachiasmatic nucleus demonstrate diurnal variation. Brain Res 497, 374-7.

[20] Kalsbeek, A., Buijs, R.M., Engelmann, M., Wotjak, C.T. and Landgraf, R. (1995) In vivo measurement of a diurnal variation in vasopressin release in the rat suprachiasmatic nucleus. Brain Res 682, 75-82.

[21] Palm, I.F., Van Der Beek, E.M., Wiegant, V.M., Buijs, R.M. and Kalsbeek, A. (1999) Vasopressin induces a luteinizing hormone surge in ovariectomized, estradiol-treated rats with lesions of the suprachiasmatic nucleus. Neuroscience 93, 659-66.

[22] Funabashi, T., Aiba, S., Sano, A., Shinohara, K. and Kimura, F. (1999) Intracerebroventricular injection of arginine-vasopressin V1 receptor antagonist attenuates the surge of luteinizing hormone and prolactin secretion in proestrous rats. Neurosci Lett 260, 37-40.

[23] van der Beek, E.M., Wiegant, V.M., van der Donk, H.A., van den Hurk, R. and Buijs, R.M. (1993) Lesions of the suprachiasmatic nucleus indicate the presence of a direct vasoactive intestinal polypeptide-containing projection to gonadotrophin-releasing hormone neurons in the female rat. J Neuroendocrinol 5, 137-44.

[24] Van Der Beek, E.M., Horvath, T.L., Wiegant, V.M., Van Den Hurk, R. and Buijs, R.M. (1997) Evidence for a direct neuronal pathway from the suprachiasmatic nucleus to the gonadotropin-releasing hormone system: Combined tracing and light and electron microscopic immunocytochemical studies. The Journal of Comparative Neurology 384, 569579.

[25] Smith, M.J., Jiennes, L. and Wise, P.M. (2000) Localization of the VIP2 receptor protein on GnRH neurons in the female rat. Endocrinology 141, 4317-20.

[26] Horvath, T.L., Cela, V. and van der Beek, E.M. (1998) Gender-specific apposition between vasoactive intestinal peptide-containing axons and gonadotrophin-releasing hormoneproducing neurons in the rat. Brain Research 795, 277-281.

[27] Christian, C.A. and Moenter, S.M. (2008) Vasoactive intestinal polypeptide can excite gonadotropin-releasing hormone neurons in a manner dependent on estradiol and gated by time of day. Endocrinology 149, 3130-6.

[28] van der Beek, E.M., Swarts, H.J. and Wiegant, V.M. (1999) Central administration of antiserum to vasoactive intestinal peptide delays and reduces luteinizing hormone and prolactin surges in ovariectomized, estrogen-treated rats. Neuroendocrinology 69, 227-37.

[29] Lee, J.H., Miele, M.E., Hicks, D.J., Phillips, K.K., Trent, J.M., Weissman, B.E. and Welch, D.R. (1996) KiSS-1, a novel human malignant melanoma metastasis-suppressor gene. Journal of the National Cancer Institute 88, 1731-1737.

[30] Kotani, M., Detheux, M., Vandenbogaerde, A., Communi, D., Vanderwinden, J.M., Le Poul, E., Brezillon, S., Tyldesley, R., Suarez-Huerta, N., Vandeput, F., Blanpain, C., Schiffmann, S.N., Vassart, G. and Parmentier, M. (2001) The Metastasis Suppressor Gene KiSS-1 Encodes Kisspeptins, the Natural Ligands of the Orphan G Protein-coupled Receptor GPR54. Journal of Biological Chemistry 276, 34631-34636.

[31] Muir, A.I., Chamberlain, L., Elshourbagy, N.A., Michalovich, D., Moore, D.J., Calamari, A., Szekeres, P.G., Sarau, H.M., Chambers, J.K., Murdock, P., Steplewski, K., Shabon, U., Miller, J.E., Middleton, S.E., Darker, J.G., Larminie, C.G., Wilson, S., Bergsma, D.J., Emson, P., Faull, R., Philpott, K.L. and Harrison, D.C. (2001) AXOR12, a novel human G protein-coupled receptor, activated by the peptide KiSS-1. The Journal of Biological Chemistry 276, 2896928975.

[32] Ohtaki, T., Shintani, Y., Honda, S., Matsumoto, H., Hori, A., Kanehashi, K., Terao, Y., Kumano, S., Takatsu, Y., Masuda, Y., Ishibashi, Y., Watanabe, T., Asada, M., Yamada, T., Suenaga, M., Kitada, C., Usuki, S., Kurokawa, T., Onda, H., Nishimura, O. and Fujino, M. (2001) Metastasis 
suppressor gene KiSS-1 encodes peptide ligand of a G-protein-coupled receptor. Nature 411, 613-617.

[33] de Roux, N., Genin, E., Carel, J.-C., Matsuda, F., Chaussain, J.-L. and Milgrom, E. (2003) Hypogonadotropic hypogonadism due to loss of function of the KiSS1-derived peptide receptor GPR54. Proceedings of the National Academy of Sciences of the United States of America 100, 10972-10976.

[34] Seminara, S.B., Messager, S., Chatzidaki, E.E., Thresher, R.R., Acierno, J.S., Shagoury, J.K., BoAbbas, Y., Kuohung, W., Schwinof, K.M., Hendrick, A.G., Zahn, D., Dixon, J., Kaiser, U.B., Slaugenhaupt, S.A., Gusella, J.F., O'Rahilly, S., Carlton, M.B.L., Crowley, W.F., Aparicio, S.A.J.R. and Colledge, W.H. (2003) The GPR54 gene as a regulator of puberty. The New England Journal of Medicine 349, 1614-1627.

[35] Smith, J.T., Dungan, H.M., Stoll, E.A., Gottsch, M.L., Braun, R.E., Eacker, S.M., Clifton, D.K. and Steiner, R.A. (2005) Differential regulation of KiSS-1 mRNA expression by sex steroids in the brain of the male mouse. Endocrinology 146, 2976-2984.

[36] Smith, J.T., Cunningham, M.J., Rissman, E.F., Clifton, D.K. and Steiner, R.A. (2005) Regulation of Kiss1 gene expression in the brain of the female mouse. Endocrinology 146, 3686-3692.

[37] Clarkson, J., d'Anglemont de Tassigny, X., Moreno, A.S., Colledge, W.H. and Herbison, A.E. (2008) Kisspeptin-GPR54 signaling is essential for preovulatory gonadotropin-releasing hormone neuron activation and the luteinizing hormone surge. The Journal of Neuroscience: The Official Journal of the Society for Neuroscience 28, 8691-8697.

[38] Smith, J.T., Popa, S.M., Clifton, D.K., Hoffman, G.E. and Steiner, R.A. (2006) Kiss1 neurons in the forebrain as central processors for generating the preovulatory luteinizing hormone surge. J Neurosci 26, 6687-94.

[39] Dror, T., Franks, J. and Kauffman, A.S. (2013) Analysis of multiple positive feedback paradigms demonstrates a complete absence of $\mathrm{LH}$ surges and $\mathrm{GnRH}$ activation in mice lacking kisspeptin signaling. Biol Reprod 88, 146.

[40] Li, X.F., Kinsey-Jones, J.S., Cheng, Y., Knox, A.M., Lin, Y., Petrou, N.A., Roseweir, A., Lightman, S.L., Milligan, S.R., Millar, R.P. and O'Byrne, K.T. (2009) Kisspeptin signalling in the hypothalamic arcuate nucleus regulates GnRH pulse generator frequency in the rat. PLoS One 4, e8334.

[41] Mittelman-Smith, M.A., Williams, H., Krajewski-Hall, S.J., Lai, J., Ciofi, P., McMullen, N.T. and Rance, N.E. (2012) Arcuate kisspeptin/neurokinin B/dynorphin (KNDy) neurons mediate the estrogen suppression of gonadotropin secretion and body weight. Endocrinology 153, 280012.

[42] Clarkson, J. and Herbison, A.E. (2006) Postnatal development of kisspeptin neurons in mouse hypothalamus; sexual dimorphism and projections to gonadotropin-releasing hormone neurons. Endocrinology 147, 5817-5825.

[43] Desroziers, E., Mikkelsen, J., Simonneaux, V., Keller, M., Tillet, Y., Caraty, A. and Franceschini, I. (2010) Mapping of kisspeptin fibres in the brain of the pro-oestrous rat. Journal of Neuroendocrinology 22, 1101-1112.

[44] Yip, S.H., Boehm, U., Herbison, A.E. and Campbell, R.E. (2015) Conditional Viral Tract Tracing Delineates the Projections of the Distinct Kisspeptin Neuron Populations to GonadotropinReleasing Hormone (GnRH) Neurons in the Mouse. Endocrinology 156, 2582-2594.

[45] True, C., Kirigiti, M., Ciofi, P., Grove, K.L. and Smith, M.S. (2011) Characterisation of arcuate nucleus kisspeptin/neurokinin $B$ neuronal projections and regulation during lactation in the rat. J Neuroendocrinol 23, 52-64.

[46] Yeo, S.H. and Herbison, A.E. (2011) Projections of arcuate nucleus and rostral periventricular kisspeptin neurons in the adult female mouse brain. Endocrinology 152, 2387-99.

[47] lijima, N., Takumi, K., Matsumoto, K. and Ozawa, H. (2015) Visualization of Kisspeptin Binding to Rat Hypothalamic Neurons. Acta Histochem Cytochem 48, 179-84. 
[48] Pielecka-Fortuna, J., Chu, Z. and Moenter, S.M. (2008) Kisspeptin acts directly and indirectly to increase gonadotropin-releasing hormone neuron activity and its effects are modulated by estradiol. Endocrinology 149, 1979-86.

[49] Gottsch, M.L., Cunningham, M.J., Smith, J.T., Popa, S.M., Acohido, B.V., Crowley, W.F., Seminara, S., Clifton, D.K. and Steiner, R.A. (2004) A role for kisspeptins in the regulation of gonadotropin secretion in the mouse. Endocrinology 145, 4073-4077.

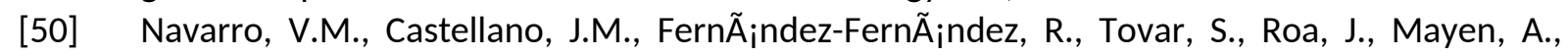
Nogueiras, R., Vazquez, M.J., Barreiro, M.L., Magni, P., Aguilar, E., Dieguez, C., Pinilla, L. and Tena-Sempere, M. (2005) Characterization of the potent luteinizing hormone-releasing activity of KiSS-1 peptide, the natural ligand of GPR54. Endocrinology 146, 156-163.

[51] Fu, L.Y. and van den Pol, A.N. (2010) Kisspeptin directly excites anorexigenic proopiomelanocortin neurons but inhibits orexigenic neuropeptide $Y$ cells by an indirect synaptic mechanism. J Neurosci 30, 10205-19.

[52] Herbison, A.E., de Tassigny, X., Doran, J. and Colledge, W.H. (2010) Distribution and postnatal development of Gpr54 gene expression in mouse brain and gonadotropin-releasing hormone neurons. Endocrinology 151, 312-21.

[53] Messager, S., Chatzidaki, E.E., Ma, D., Hendrick, A.G., Zahn, D., Dixon, J., Thresher, R.R., Malinge, I., Lomet, D., Carlton, M.B., Colledge, W.H., Caraty, A. and Aparicio, S.A. (2005) Kisspeptin directly stimulates gonadotropin-releasing hormone release via $\mathrm{G}$ protein-coupled receptor 54. Proc Natl Acad Sci U S A 102, 1761-6.

[54] Kauffman, A.S., Gottsch, M.L., Roa, J., Byquist, A.C., Crown, A., Clifton, D.K., Hoffman, G.E., Steiner, R.A. and Tena-Sempere, M. (2007) Sexual differentiation of Kiss1 gene expression in the brain of the rat. Endocrinology 148, 1774-1783.

[55] Gill, J.C., Wang, O., Kakar, S., Martinelli, E., Carroll, R.S. and Kaiser, U.B. (2010) Reproductive hormone-dependent and -independent contributions to developmental changes in kisspeptin in GnRH-deficient hypogonadal mice. PLoS One 5, e11911.

[56] Tsukamura, H., Homma, T., Tomikawa, J., Uenoyama, Y. and Maeda, K. (2010) Sexual differentiation of kisspeptin neurons responsible for sex difference in gonadotropin release in rats. Ann N Y Acad Sci 1200, 95-103.

[57] Cheng, G., Coolen, L.M., Padmanabhan, V., Goodman, R.L. and Lehman, M.N. (2010) The kisspeptin/neurokinin B/dynorphin (KNDy) cell population of the arcuate nucleus: sex differences and effects of prenatal testosterone in sheep. Endocrinology 151, 301-11.

[58] Overgaard, A., Tena-Sempere, M., Franceschini, I., Desroziers, E., Simonneaux, V. and Mikkelsen, J.D. (2013) Comparative analysis of kisspeptin-immunoreactivity reveals genuine differences in the hypothalamic Kiss1 systems between rats and mice. Peptides 45, 85-90.

[59] Hrabovszky, E., Ciofi, P., Vida, B., Horvath, M.C., Keller, E., Caraty, A., Bloom, S.R., Ghatei, M.A., Dhillo, W.S., Liposits, Z. and Kallo, I. (2010) The kisspeptin system of the human hypothalamus: sexual dimorphism and relationship with gonadotropin-releasing hormone and neurokinin B neurons. Eur J Neurosci 31, 1984-98.

[60] de Croft, S., Piet, R., Mayer, C., Mai, O., Boehm, U. and Herbison, A.E. (2012) Spontaneous kisspeptin neuron firing in the adult mouse reveals marked sex and brain region differences but no support for a direct role in negative feedback. Endocrinology 153, 5384-93.

[61] Adachi, S., Yamada, S., Takatsu, Y., Matsui, H., Kinoshita, M., Takase, K., Sugiura, H., Ohtaki, T., Matsumoto, H., Uenoyama, Y., Tsukamura, H., Inoue, K. and Maeda, K.-I. (2007) Involvement of anteroventral periventricular metastin/kisspeptin neurons in estrogen positive feedback action on luteinizing hormone release in female rats. The Journal of Reproduction and Development 53, 367-378.

[62] Robertson, J.L., Clifton, D.K., de la Iglesia, H.O., Steiner, R.A. and Kauffman, A.S. (2009) Circadian regulation of Kiss1 neurons: implications for timing the preovulatory gonadotropinreleasing hormone/luteinizing hormone surge. Endocrinology 150, 3664-3671. 
[63] Chassard, D., Bur, I., Poirel, V.J., Mendoza, J. and Simonneaux, V. (2015) Evidence for a Putative Circadian Kiss-Clock in the Hypothalamic AVPV in Female Mice. Endocrinology 156, 2999-3011.

[64] Ducret, E., Gaidamaka, G. and Herbison, A.E. (2010) Electrical and morphological characteristics of anteroventral periventricular nucleus kisspeptin and other neurons in the female mouse. Endocrinology 151, 2223-2232.

[65] Vida, B., Deli, L., Hrabovszky, E., Kalamatianos, T., Caraty, A., Coen, C.W., Liposits, Z. and Kall $\tilde{A}^{3}$, I. (2010) Evidence for suprachiasmatic vasopressin neurones innervating kisspeptin neurones in the rostral periventricular area of the mouse brain: regulation by oestrogen. Journal of Neuroendocrinology 22, 1032-1039.

[66] Williams, W.P., Jarjisian, S.G., Mikkelsen, J.D. and Kriegsfeld, L.J. (2011) Circadian Control of Kisspeptin and a Gated GnRH Response Mediate the Preovulatory Luteinizing Hormone Surge. Endocrinology 152, 595-606.

[67] Piet, R., Fraissenon, A., Boehm, U. and Herbison, A.E. (2015) Estrogen Permits Vasopressin Signaling in Preoptic Kisspeptin Neurons in the Female Mouse. Journal of Neuroscience 35, 6881-6892.

[68] Palm, I.F., van der Beek, E.M., Wiegant, V.M., Buijs, R.M. and Kalsbeek, A. (2001) The stimulatory effect of vasopressin on the luteinizing hormone surge in ovariectomized, estradiol-treated rats is time-dependent. Brain Res 901, 109-16.

[69] Tsutsui, K., Saigoh, E., Ukena, K., Teranishi, H., Fujisawa, Y., Kikuchi, M., Ishii, S. and Sharp, P.J. (2000) A novel avian hypothalamic peptide inhibiting gonadotropin release. Biochem Biophys Res Commun 275, 661-7.

[70] Hinuma, S., Shintani, Y., Fukusumi, S., lijima, N., Matsumoto, Y., Hosoya, M., Fujii, R., Watanabe, T., Kikuchi, K., Terao, Y., Yano, T., Yamamoto, T., Kawamata, Y., Habata, Y., Asada, M., Kitada, C., Kurokawa, T., Onda, H., Nishimura, O., Tanaka, M., Ibata, Y. and Fujino, M. (2000) New neuropeptides containing carboxy-terminal RFamide and their receptor in mammals. Nat Cell Biol 2, 703-8.

[71] Fukusumi, S., Habata, Y., Yoshida, H., lijima, N., Kawamata, Y., Hosoya, M., Fujii, R., Hinuma, S., Kitada, C., Shintani, Y., Suenaga, M., Onda, H., Nishimura, O., Tanaka, M., Ibata, Y. and Fujino, M. (2001) Characteristics and distribution of endogenous RFamide-related peptide-1. Biochim Biophys Acta 1540, 221-32.

[72] Ukena, K., Iwakoshi, E., Minakata, H. and Tsutsui, K. (2002) A novel rat hypothalamic RFamide-related peptide identified by immunoaffinity chromatography and mass spectrometry. FEBS Lett 512, 255-8.

[73] Anderson, G.M., Relf, H.L., Rizwan, M.Z. and Evans, J.J. (2009) Central and peripheral effects of RFamide-related peptide-3 on luteinizing hormone and prolactin secretion in rats. Endocrinology 150, 1834-40.

[74] Clarke, I.J., Sari, I.P., Qi, Y., Smith, J.T., Parkington, H.C., Ubuka, T., Iqbal, J., Li, Q., Tilbrook, A., Morgan, K., Pawson, A.J., Tsutsui, K., Millar, R.P. and Bentley, G.E. (2008) Potent action of RFamide-related peptide-3 on pituitary gonadotropes indicative of a hypophysiotropic role in the negative regulation of gonadotropin secretion. Endocrinology 149, 5811-21.

[75] Ducret, E., Anderson, G.M. and Herbison, A.E. (2009) RFamide-related peptide-3, a mammalian gonadotropin-inhibitory hormone ortholog, regulates gonadotropin-releasing hormone neuron firing in the mouse. Endocrinology 150, 2799-804.

[76] Johnson, M.A., Tsutsui, K. and Fraley, G.S. (2007) Rat RFamide-related peptide-3 stimulates $\mathrm{GH}$ secretion, inhibits LH secretion, and has variable effects on sex behavior in the adult male rat. Horm Behav 51, 171-80.

[77] Kriegsfeld, L.J., Mei, D.F., Bentley, G.E., Ubuka, T., Mason, A.O., Inoue, K., Ukena, K., Tsutsui, K. and Silver, R. (2006) Identification and characterization of a gonadotropin-inhibitory system in the brains of mammals. Proc Natl Acad Sci U S A 103, 2410-5.

[78] Pineda, R., Garcia-Galiano, D., Sanchez-Garrido, M.A., Romero, M., Ruiz-Pino, F., Aguilar, E., Dijcks, F.A., Blomenrohr, M., Pinilla, L., van Noort, P.I. and Tena-Sempere, M. (2010) 
Characterization of the inhibitory roles of RFRP3, the mammalian ortholog of $\mathrm{GnIH}$, in the control of gonadotropin secretion in the rat: in vivo and in vitro studies. Am J Physiol Endocrinol Metab 299, E39-46.

[79] Leon, S., Garcia-Galiano, D., Ruiz-Pino, F., Barroso, A., Manfredi-Lozano, M., Romero-Ruiz, A., Roa, J., Vazquez, M.J., Gaytan, F., Blomenrohr, M., van Duin, M., Pinilla, L. and Tena-Sempere, M. (2014) Physiological roles of gonadotropin-inhibitory hormone signaling in the control of mammalian reproductive axis: studies in the NPFF1 receptor null mouse. Endocrinology 155, 2953-65.

[80] Ancel, C., Bentsen, A.H., Sebert, M.E., Tena-Sempere, M., Mikkelsen, J.D. and Simonneaux, V. (2012) Stimulatory effect of RFRP-3 on the gonadotrophic axis in the male Syrian hamster: the exception proves the rule. Endocrinology 153, 1352-63.

[81] Ubuka, T., Inoue, K., Fukuda, Y., Mizuno, T., Ukena, K., Kriegsfeld, L.J. and Tsutsui, K. (2012) Identification, expression, and physiological functions of Siberian hamster gonadotropininhibitory hormone. Endocrinology 153, 373-85.

[82] Henningsen, J.B., Poirel, V.J., Mikkelsen, J.D., Tsutsui, K., Simonneaux, V. and Gauer, F. (2015) Sex differences in the photoperiodic regulation of RF-amide related peptide (RFRP) and its receptor GPR147 in the Syrian hamster. J Comp Neurol.

[83] Rizwan, M.Z., Poling, M.C., Corr, M., Cornes, P.A., Augustine, R.A., Quennell, J.H., Kauffman, A.S. and Anderson, G.M. (2012) RFamide-related peptide-3 receptor gene expression in $\mathrm{GnRH}$ and kisspeptin neurons and GnRH-dependent mechanism of action. Endocrinology 153, 3770-9.

[84] Smith, J.T., Coolen, L.M., Kriegsfeld, L.J., Sari, I.P., Jaafarzadehshirazi, M.R., Maltby, M., Bateman, K., Goodman, R.L., Tilbrook, A.J., Ubuka, T., Bentley, G.E., Clarke, I.J. and Lehman, M.N. (2008) Variation in kisspeptin and RFamide-related peptide (RFRP) expression and terminal connections to gonadotropin-releasing hormone neurons in the brain: a novel medium for seasonal breeding in the sheep. Endocrinology 149, 5770-82.

[85] Poling, M.C., Quennell, J.H., Anderson, G.M. and Kauffman, A.S. (2013) Kisspeptin neurones do not directly signal to RFRP-3 neurones but RFRP-3 may directly modulate a subset of hypothalamic kisspeptin cells in mice. J Neuroendocrinol 25, 876-86.

[86] Poling, M.C., Kim, J., Dhamija, S. and Kauffman, A.S. (2012) Development, sex steroid regulation, and phenotypic characterization of RFamide-related peptide (Rfrp) gene expression and RFamide receptors in the mouse hypothalamus. Endocrinology 153, 1827-40.

[87] Gouarderes, C., Mazarguil, H., Mollereau, C., Chartrel, N., Leprince, J., Vaudry, H. and Zajac, J.M. (2007) Functional differences between NPFF1 and NPFF2 receptor coupling: high intrinsic activities of RFamide-related peptides on stimulation of [35S]GTPgammaS binding. Neuropharmacology 52, 376-86.

[88] Bonini, J.A., Jones, K.A., Adham, N., Forray, C., Artymyshyn, R., Durkin, M.M., Smith, K.E., Tamm, J.A., Boteju, L.W., Lakhlani, P.P., Raddatz, R., Yao, W.J., Ogozalek, K.L., Boyle, N., Kouranova, E.V., Quan, Y., Vaysse, P.J., Wetzel, J.M., Branchek, T.A., Gerald, C. and Borowsky, B. (2000) Identification and characterization of two $G$ protein-coupled receptors for neuropeptide FF. The Journal of Biological Chemistry 275, 39324-39331.

[89] Mollereau, C., Mazarguil, H., Marcus, D., Quelven, I., Kotani, M., Lannoy, V., Dumont, Y., Quirion, R.m., Detheux, M., Parmentier, M. and Zajac, J.-M. (2002) Pharmacological characterization of human NPFF(1) and NPFF(2) receptors expressed in $\mathrm{CHO}$ cells by using NPY Y(1) receptor antagonists. European Journal of Pharmacology 451, 245-256.

[90] Gouarderes, C., Faura, C.C. and Zajac, J.M. (2004) Rodent strain differences in the NPFF1 and NPFF2 receptor distribution and density in the central nervous system. Brain Res 1014, 6170.

[91] Dardente, H., Birnie, M., Lincoln, G.A. and Hazlerigg, D.G. (2008) RFamide-related peptide and its cognate receptor in the sheep: cDNA cloning, mRNA distribution in the hypothalamus and the effect of photoperiod. J Neuroendocrinol 20, 1252-9. 
[92] Jorgensen, S.R., Andersen, M.D., Overgaard, A. and Mikkelsen, J.D. (2014) Changes in RFamide-related peptide-1 (RFRP-1)-immunoreactivity during postnatal development and the estrous cycle. Endocrinology 155, 4402-10.

[93] Gibson, E.M., Humber, S.A., Jain, S., Williams, W.P., 3rd, Zhao, S., Bentley, G.E., Tsutsui, K. and Kriegsfeld, L.J. (2008) Alterations in RFamide-related peptide expression are coordinated with the preovulatory luteinizing hormone surge. Endocrinology 149, 4958-69.

[94] Clarke, I.J., Smith, J.T., Henry, B.A., Oldfield, B.J., Stefanidis, A., Millar, R.P., Sari, I.P., Chng, K., Fabre-Nys, C., Caraty, A., Ang, B.T., Chan, L. and Fraley, G.S. (2012) Gonadotropin-inhibitory hormone is a hypothalamic peptide that provides a molecular switch between reproduction and feeding. Neuroendocrinology 95, 305-316.

[95] Russo, K.A., La, J.L., Stephens, S.B., Poling, M.C., Padgaonkar, N.A., Jennings, K.J., Piekarski, D.J., Kauffman, A.S. and Kriegsfeld, L.J. (2015) Circadian Control of the Female Reproductive Axis Through Gated Responsiveness of the RFRP-3 System to VIP Signaling. Endocrinology 156, 2608-18.

[96] Murakami, M., Matsuzaki, T., Iwasa, T., Yasui, T., Irahara, M., Osugi, T. and Tsutsui, K. (2008) Hypophysiotropic role of RFamide-related peptide- 3 in the inhibition of $\mathrm{LH}$ secretion in female rats. J Endocrinol 199, 105-12.

[97] Caraty, A., BlomenrÃThr, M., Vogel, G.M.T., Lomet, D., Briant, C. and Beltramo, M. (2012) RF9 powerfully stimulates gonadotrophin secretion in the ewe: evidence for a seasonal threshold of sensitivity. Journal of Neuroendocrinology 24, 725-736.

[98] Decourt, C., Anger, K., Robert, V., Lomet, D., Bartzen-Sprauer, J., Caraty, A., Dufourny, L., Anderson, G. and Beltramo, M. (2016) No evidence that RFamide related peptide 3 directly modulates LH secretion in the ewe. Endocrinology, en20151854.

[99] Mayer, C., Acosta-Martinez, M., Dubois, S.L., Wolfe, A., Radovick, S., Boehm, U. and Levine, J.E. (2010) Timing and completion of puberty in female mice depend on estrogen receptor alpha-signaling in kisspeptin neurons. Proceedings of the National Academy of Sciences of the United States of America 107, 22693-22698.

[100] Dubois, S.L., Acosta-Martinez, M., DeJoseph, M.R., Wolfe, A., Radovick, S., Boehm, U., Urban, J.H. and Levine, J.E. (2015) Positive, but not negative feedback actions of estradiol in adult female mice require estrogen receptor alpha in kisspeptin neurons. Endocrinology 156, 111120.

[101] Molnar, C.S., Kallo, I., Liposits, Z. and Hrabovszky, E. (2011) Estradiol down-regulates RFamide-related peptide (RFRP) expression in the mouse hypothalamus. Endocrinology 152, 1684-90.

[102] Iwasa, T., Matsuzaki, T., Murakami, M., Kinouchi, R., Osugi, T., Gereltsetseg, G., Yoshida, S., Irahara, M. and Tsutsui, K. (2012) Developmental changes in the mammalian gonadotropininhibitory hormone (GnIH) ortholog RFamide-related peptide (RFRP) and its cognate receptor GPR147 in the rat hypothalamus. Int J Dev Neurosci 30, 31-7.

[103] Quennell, J.H., Rizwan, M.Z., Relf, H.L. and Anderson, G.M. (2010) Developmental and steroidogenic effects on the gene expression of RFamide related peptides and their receptor in the rat brain and pituitary gland. J Neuroendocrinol 22, 309-16.

[104] Herbison, A.E. (2008) Estrogen positive feedback to gonadotropin-releasing hormone (GnRH) neurons in the rodent: the case for the rostral periventricular area of the third ventricle (RP3V). Brain Res Rev 57, 277-87.

[105] Rometo, A.M., Krajewski, S.J., Voytko, M.L. and Rance, N.E. (2007) Hypertrophy and increased kisspeptin gene expression in the hypothalamic infundibular nucleus of postmenopausal women and ovariectomized monkeys. J Clin Endocrinol Metab 92, 2744-50.

[106] Hrabovszky, E. (2014) Neuroanatomy of the human hypothalamic kisspeptin system. Neuroendocrinology 99, 33-48.

[107] Topaloglu, A.K., Reimann, F., Guclu, M., Yalin, A.S., Kotan, L.D., Porter, K.M., Serin, A., Mungan, N.O., Cook, J.R., Ozbek, M.N., Imamoglu, S., Akalin, N.S., Yuksel, B., O'Rahilly, S. and 
Semple, R.K. (2009) TAC3 and TACR3 mutations in familial hypogonadotropic hypogonadism reveal a key role for Neurokinin B in the central control of reproduction. Nat Genet 41, 354-8.

[108] Young, J., Bouligand, J., Francou, B., Raffin-Sanson, M.L., Gaillez, S., Jeanpierre, M., Grynberg, M., Kamenicky, P., Chanson, P., Brailly-Tabard, S. and Guiochon-Mantel, A. (2010) TAC3 and TACR3 defects cause hypothalamic congenital hypogonadotropic hypogonadism in humans. J Clin Endocrinol Metab 95, 2287-95.

[109] Ubuka, T., Morgan, K., Pawson, A.J., Osugi, T., Chowdhury, V.S., Minakata, H., Tsutsui, K., Millar, R.P. and Bentley, G.E. (2009) Identification of human GnIH homologs, RFRP-1 and RFRP-3, and the cognate receptor, GPR147 in the human hypothalamic pituitary axis. PLoS One 4, e8400.

[110] Topaloglu, A.K., Tello, J.A., Kotan, L.D., Ozbek, M.N., Yilmaz, M.B., Erdogan, S., Gurbuz, F., Temiz, F., Millar, R.P. and Yuksel, B. (2012) Inactivating KISS1 mutation and hypogonadotropic hypogonadism. N Engl J Med 366, 629-35.

[111] Teles, M.G., Trarbach, E.B., Noel, S.D., Guerra-Junior, G., Jorge, A., Beneduzzi, D., Bianco, S.D., Mukherjee, A., Baptista, M.T., Costa, E.M., De Castro, M., Mendonca, B.B., Kaiser, U.B. and Latronico, A.C. (2010) A novel homozygous splice acceptor site mutation of KISS1R in two siblings with normosmic isolated hypogonadotropic hypogonadism. Eur J Endocrinol 163, 2934.

[112] Breuer, O., Abdulhadi-Atwan, M., Zeligson, S., Fridman, H., Renbaum, P., Levy-Lahad, E. and Zangen, D.H. (2012) A novel severe N-terminal splice site KISS1R gene mutation causes hypogonadotropic hypogonadism but enables a normal development of neonatal external genitalia. Eur J Endocrinol 167, 209-16.

[113] Brioude, F., Bouligand, J., Francou, B., Fagart, J., Roussel, R., Viengchareun, S., Combettes, L., Brailly-Tabard, S., Lombes, M., Young, J. and Guiochon-Mantel, A. (2013) Two families with normosmic congenital hypogonadotropic hypogonadism and biallelic mutations in KISS1R (KISS1 receptor): clinical evaluation and molecular characterization of a novel mutation. PLoS One 8, e53896.

[114] Demirbilek, H., Ozbek, M.N., Demir, K., Kotan, L.D., Cesur, Y., Dogan, M., Temiz, F., Mengen, E., Gurbuz, F., Yuksel, B. and Topaloglu, A.K. (2015) Normosmic idiopathic hypogonadotropic hypogonadism due to a novel homozygous nonsense c.C969A (p.Y323X) mutation in the KISS1R gene in three unrelated families. Clin Endocrinol (Oxf) 82, 429-38.

[115] Francou, B., Paul, C., Amazit, L., Cartes, A., Bouvattier, C., Albarel, F., Maiter, D., Chanson, P., Trabado, S., Brailly-Tabard, S., Brue, T., Guiochon-Mantel, A., Young, J. and Bouligand, J. (2016) Prevalence of KISS1 Receptor mutations in a series of 603 patients with normosmic congenital hypogonadotrophic hypogonadism and characterization of novel mutations: a single-centre study. Hum Reprod 31, 1363-74.

[116] Teles, M.G., Bianco, S.D., Brito, V.N., Trarbach, E.B., Kuohung, W., Xu, S., Seminara, S.B., Mendonca, B.B., Kaiser, U.B. and Latronico, A.C. (2008) A GPR54-activating mutation in a patient with central precocious puberty. N Engl J Med 358, 709-15.

[117] Lima, C.J., Cardoso, S.C., Lemos, E.F., Zingler, E., Capanema, C., Menezes, L.D., Vogado, G., Dos Santos, B.T., de Moraes, O.L., Duarte, E.F., de Brito, V.N., Latronico, A.C. and LofranoPorto, A. (2014) Mutational analysis of the genes encoding RFamide-related peptide-3, the human orthologue of gonadotrophin-inhibitory hormone, and its receptor (GPR147) in patients with gonadotrophin-releasing hormone-dependent pubertal disorders. J Neuroendocrinol 26, 817-24.

[118] Oishi, H., Klausen, C., Bentley, G.E., Osugi, T., Tsutsui, K., Gilks, C.B., Yano, T. and Leung, P.C. (2012) The human gonadotropin-inhibitory hormone ortholog RFamide-related peptide-3 suppresses gonadotropin-induced progesterone production in human granulosa cells. Endocrinology 153, 3435-45.

[119] Shahab, M., Mastronardi, C., Seminara, S.B., Crowley, W.F., Ojeda, S.R. and Plant, T.M. (2005) Increased hypothalamic GPR54 signaling: a potential mechanism for initiation of puberty in primates. Proc Natl Acad Sci U S A 102, 2129-34. 
[120] Smith, J.T., Shahab, M., Pereira, A., Pau, K.Y. and Clarke, I.J. (2010) Hypothalamic expression of KISS1 and gonadotropin inhibitory hormone genes during the menstrual cycle of a nonhuman primate. Biol Reprod 83, 568-77.

[121] Horikoshi, Y., Matsumoto, H., Takatsu, Y., Ohtaki, T., Kitada, C., Usuki, S. and Fujino, M. (2003) Dramatic elevation of plasma metastin concentrations in human pregnancy: metastin as a novel placenta-derived hormone in humans. J Clin Endocrinol Metab 88, 914-9.

[122] Francis, V.A., Abera, A.B., Matjila, M., Millar, R.P. and Katz, A.A. (2014) Kisspeptin regulation of genes involved in cell invasion and angiogenesis in first trimester human trophoblast cells. PLoS One 9, e99680.

[123] Kavvasoglu, S., Ozkan, Z.S., Kumbak, B., Simsek, M. and Ilhan, N. (2012) Association of kisspeptin-10 levels with abortus imminens: a preliminary study. Arch Gynecol Obstet 285, 649-53.

[124] Wu, S., Zhang, H., Tian, J., Liu, L., Dong, Y. and Mao, T. (2014) Expression of kisspeptin/GPR54 and PIBF/PR in the first trimester trophoblast and decidua of women with recurrent spontaneous abortion. Pathol Res Pract 210, 47-54.

[125] Cetkovic, A., Miljic, D., Ljubic, A., Patterson, M., Ghatei, M., Stamenkovic, J., Nikolic-Djurovic, M., Pekic, S., Doknic, M., Glisic, A., Bloom, S. and Popovic, V. (2012) Plasma kisspeptin levels in pregnancies with diabetes and hypertensive disease as a potential marker of placental dysfunction and adverse perinatal outcome. Endocr Res 37, 78-88.

[126] Cartwright, J.E. and Williams, P.J. (2012) Altered placental expression of kisspeptin and its receptor in pre-eclampsia. J Endocrinol 214, 79-85.

[127] Logie, J.J., Denison, F.C., Riley, S.C., Ramaesh, T., Forbes, S., Norman, J.E. and Reynolds, R.M. (2012) Evaluation of kisspeptin levels in obese pregnancy as a biomarker for pre-eclampsia. Clin Endocrinol (Oxf) 76, 887-93.

[128] Armstrong, R.A., Reynolds, R.M., Leask, R., Shearing, C.H., Calder, A.A. and Riley, S.C. (2009) Decreased serum levels of kisspeptin in early pregnancy are associated with intra-uterine growth restriction and pre-eclampsia. Prenat Diagn 29, 982-5.

[129] Calder, M., Chan, Y.M., Raj, R., Pampillo, M., Elbert, A., Noonan, M., Gillio-Meina, C., Caligioni, C., Berube, N.G., Bhattacharya, M., Watson, A.J., Seminara, S.B. and Babwah, A.V. (2014) Implantation failure in female Kiss1-/- mice is independent of their hypogonadic state and can be partially rescued by leukemia inhibitory factor. Endocrinology 155, 3065-78.

[130] Mittelman-Smith, M.A., Williams, H., Krajewski-Hall, S.J., McMullen, N.T. and Rance, N.E. (2012) Role for kisspeptin/neurokinin B/dynorphin (KNDy) neurons in cutaneous vasodilatation and the estrogen modulation of body temperature. Proc Natl Acad Sci U S A 109, 19846-51.

[131] Santoro, N., Filicori, M. and Crowley, W.F., Jr. (1986) Hypogonadotropic disorders in men and women: diagnosis and therapy with pulsatile gonadotropin-releasing hormone. Endocr Rev 7, 11-23.

[132] Grimes, E.M., Taymor, M.L. and Thompson, I.E. (1975) Induction of timed ovulation with synthetic luteinizing hormone-releasing hormone in women undergoing insemination therapy. I. Effect of a single parenteral administration at midcycle. Fertil Steril 26, 277-82.

[133] Belchetz, P.E., Plant, T.M., Nakai, Y., Keogh, E.J. and Knobil, E. (1978) Hypophysial responses to continuous and intermittent delivery of hypopthalamic gonadotropin-releasing hormone. Science 202, 631-3.

[134] McArdle, C.A., Gorospe, W.C., Huckle, W.R. and Conn, P.M. (1987) Homologous downregulation of gonadotropin-releasing hormone receptors and desensitization of gonadotropes: lack of dependence on protein kinase C. Mol Endocrinol 1, 420-9.

[135] Mason, D.R., Arora, K.K., Mertz, L.M. and Catt, K.J. (1994) Homologous down-regulation of gonadotropin-releasing hormone receptor sites and messenger ribonucleic acid transcripts in alpha T3-1 cells. Endocrinology 135, 1165-70.

[136] Dhillo, W.S., Chaudhri, O.B., Thompson, E.L., Murphy, K.G., Patterson, M., Ramachandran, R., Nijher, G.K., Amber, V., Kokkinos, A., Donaldson, M., Ghatei, M.A. and Bloom, S.R. (2007) 
Kisspeptin-54 stimulates gonadotropin release most potently during the preovulatory phase of the menstrual cycle in women. J Clin Endocrinol Metab 92, 3958-66.

[137] Dhillo, W.S., Chaudhri, O.B., Patterson, M., Thompson, E.L., Murphy, K.G., Badman, M.K., McGowan, B.M., Amber, V., Patel, S., Ghatei, M.A. and Bloom, S.R. (2005) Kisspeptin-54 stimulates the hypothalamic-pituitary gonadal axis in human males. J Clin Endocrinol Metab 90, 6609-15.

[138] Jayasena, C.N., Nijher, G.M., Comninos, A.N., Abbara, A., Januszewki, A., Vaal, M.L., Sriskandarajah, L., Murphy, K.G., Farzad, Z., Ghatei, M.A., Bloom, S.R. and Dhillo, W.S. (2011) The effects of kisspeptin-10 on reproductive hormone release show sexual dimorphism in humans. J Clin Endocrinol Metab 96, E1963-72.

[139] Jayasena, C.N., Comninos, A.N., Veldhuis, J.D., Misra, S., Abbara, A., Izzi-Engbeaya, C., Donaldson, M., Ghatei, M.A., Bloom, S.R. and Dhillo, W.S. (2013) A single injection of kisspeptin-54 temporarily increases luteinizing hormone pulsatility in healthy women. Clin Endocrinol (Oxf) 79, 558-63.

[140] Jayasena, C.N., Comninos, A.N., Nijher, G.M., Abbara, A., De Silva, A., Veldhuis, J.D., Ratnasabapathy, R., Izzi-Engbeaya, C., Lim, A., Patel, D.A., Ghatei, M.A., Bloom, S.R. and Dhillo, W.S. (2013) Twice-daily subcutaneous injection of kisspeptin-54 does not abolish menstrual cyclicity in healthy female volunteers. J Clin Endocrinol Metab 98, 4464-74.

[141] Kadokawa, H., Matsui, M., Hayashi, K., Matsunaga, N., Kawashima, C., Shimizu, T., Kida, K. and Miyamoto, A. (2008) Peripheral administration of kisspeptin-10 increases plasma concentrations of GH as well as LH in prepubertal Holstein heifers. J Endocrinol 196, 331-4.

[142] Kadokawa, H., Suzuki, S. and Hashizume, T. (2008) Kisspeptin-10 stimulates the secretion of growth hormone and prolactin directly from cultured bovine anterior pituitary cells. Anim Reprod Sci 105, 404-8.

[143] Szawka, R.E., Ribeiro, A.B., Leite, C.M., Helena, C.V., Franci, C.R., Anderson, G.M., Hoffman, G.E. and Anselmo-Franci, J.A. (2010) Kisspeptin regulates prolactin release through hypothalamic dopaminergic neurons. Endocrinology 151, 3247-57.

[144] Yang, B., Jiang, Q., Chan, T., Ko, W.K. and Wong, A.O. (2010) Goldfish kisspeptin: molecular cloning, tissue distribution of transcript expression, and stimulatory effects on prolactin, growth hormone and luteinizing hormone secretion and gene expression via direct actions at the pituitary level. Gen Comp Endocrinol 165, 60-71.

[145] Luque, R.M., Cordoba-Chacon, J., Gahete, M.D., Navarro, V.M., Tena-Sempere, M., Kineman, R.D. and Castano, J.P. (2011) Kisspeptin regulates gonadotroph and somatotroph function in nonhuman primate pituitary via common and distinct signaling mechanisms. Endocrinology 152, 957-66.

[146] Ribeiro, A.B., Leite, C.M., Kalil, B., Franci, C.R., Anselmo-Franci, J.A. and Szawka, R.E. (2015) Kisspeptin regulates tuberoinfundibular dopaminergic neurones and prolactin secretion in an oestradiol-dependent manner in male and female rats. J Neuroendocrinol 27, 88-99.

[147] Jayasena, C.N., Comninos, A.N., Narayanaswamy, S., Bhalla, S., Abbara, A., Ganiyu-Dada, Z., Busbridge, M., Ghatei, M.A., Bloom, S.R. and Dhillo, W.S. (2014) Acute and chronic effects of kisspeptin-54 administration on $\mathrm{GH}$, prolactin and TSH secretion in healthy women. Clin Endocrinol (Oxf) 81, 891-8.

[148] George, J.T., Anderson, R.A. and Millar, R.P. (2012) Kisspeptin-10 stimulation of gonadotrophin secretion in women is modulated by sex steroid feedback. Hum Reprod 27, 3552-9.

[149] Chan, Y.M., Butler, J.P., Sidhoum, V.F., Pinnell, N.E. and Seminara, S.B. (2012) Kisspeptin administration to women: a window into endogenous kisspeptin secretion and GnRH responsiveness across the menstrual cycle. J Clin Endocrinol Metab 97, E1458-67.

[150] Jayasena, C.N., Nijher, G.M., Abbara, A., Murphy, K.G., Lim, A., Patel, D., Mehta, A., Todd, C., Donaldson, M., Trew, G.H., Ghatei, M.A., Bloom, S.R. and Dhillo, W.S. (2010) Twice-weekly administration of kisspeptin-54 for 8 weeks stimulates release of reproductive hormones in women with hypothalamic amenorrhea. Clin Pharmacol Ther 88, 840-7. 
[151] Jayasena, C.N., Abbara, A., Comninos, A.N., Nijher, G.M., Christopoulos, G., Narayanaswamy, S., Izzi-Engbeaya, C., Sridharan, M., Mason, A.J., Warwick, J., Ashby, D., Ghatei, M.A., Bloom, S.R., Carby, A., Trew, G.H. and Dhillo, W.S. (2014) Kisspeptin-54 triggers egg maturation in women undergoing in vitro fertilization. J Clin Invest 124, 3667-77.

[152] Abbara, A., Jayasena, C.N., Christopoulos, G., Narayanaswamy, S., Izzi-Engbeaya, C., Nijher, G.M., Comninos, A.N., Peters, D., Buckley, A., Ratnasabapathy, R., Prague, J.K., Salim, R., Lavery, S.A., Bloom, S.R., Szigeti, M., Ashby, D.A., Trew, G.H. and Dhillo, W.S. (2015) Efficacy of Kisspeptin-54 to Trigger Oocyte Maturation in Women at High Risk of Ovarian Hyperstimulation Syndrome (OHSS) During In Vitro Fertilization (IVF) Therapy. J Clin Endocrinol Metab 100, 3322-31. 